\title{
PERCEPTION OF GLOBAL SELF-ESTEEM AND BODY FAT IN ADOLESCENTS ENGAGED IN BASKETBALL
}

\author{
Vilma Medišauskaité ${ }^{1}$, Skaistė Laskiené ${ }^{2}$, Martin Sebera ${ }^{1}$ \\ Masaryk University, Faculty of Sport Studies, Brno, Czech Republic ', Lithuanian Academy of Physical \\ Education ${ }^{2}$, Kaunas, Lithuania ${ }^{2}$
}

\begin{abstract}
Vilma Medišauskaitė. PhD student in kinanthropology at the faculty of Sport Studies, Masaryk University, Brno (Czech Republic). Research interests - physical self-concept, self-esteem in adolescents engaged in sports, suicidal tendencies in adolescence.
\end{abstract}

\begin{abstract}
Mental and moral maturity, growth, appearance, physical skills are nowadays more and more often used as reference points of our identity and emphasized in adolescence (Harter, 1999). Development of physical self-concept's domains (e. g. appearance, self-esteem, physical competences, etc) has been a major concern among physical activity researchers during the last decade (Fox, 2000).

The study examined the relation between the separate specific domains of physical self-concept: global self-esteem (the overall positive or negative feeling about one's self) and body fat considering age and gender in adolescents basketball players. Global self-esteem is understood as the overall positive or negative feeling about one's self; or generalized feelings of self-worth which are not specific to a particular situation, but which apply to many activities or areas of life and predispose the subject to view new activities in particular ways (Macek, Lacinová, 2006). And body fat - an attitude towards you body fat directly (I think my stomach is too big; I have too much fat on my body; I am overweight; etc. (Marsh et al., 1994).

Our study sample consisted of 95 adolescents - basketball players (54 males and 41 females) from different sport gymnasiums and clubs in Prague and Brno (Czech Republic). The respondents were divided into two age groups $\left(I^{s t}-13-15\right.$ years of age and the $I I^{\text {nd }}-16-18$ years of age $)$.

An ordinary Introductory Questionnaire of 20 items was compiled in order to describe the population. The questionnaire was compiled by the first author of the current study. The variables were assessed by the Physical Self Description Questionnaire (PSDQ, Marsh et al., 1994). Both questionnaires were anonymous. To ensure uniformity in the administration of the questionnaire, the same set of directions were followed each time by the same researcher.

To analyze the interaction effects for our researched factors (gender and age involvement), MANOVA (Multivariate Analysis of Variance) and correlation were calculated. Significance level was chosen to be 10\%. The results proved our assumption that females tended to have more negative evaluation of the body fat then males regardless of their age. The second part focused on the measures of global self-esteem. The differences in the evaluation on global self-esteem were revealed by age, but not by gender. Global self-esteem was found to be more positive in younger adolescents — basketball players — than in older players regardless of their gender $(p<0.01)$.
\end{abstract}

Keywords: global self-esteem, body fat, adolescence, age, gender, basketball.

\section{INTRODUCTION}

$\mathrm{M}$ any scientists (e. g. Fox, 2000; Klomsten et al., 2004; Moreno, Cervello, 2005; Oweis, Spinks, 2001) acknowledge that participation in sports activity is one of the key factors contributing to the development of identity and positive self-esteem in adolescents. Positive self-esteem is an important part of human development, and sports participation is known to contribute to it. The authors mentioned above also stress that sports activity encourages communication with peers, develops physical abilities, character, creativity, the value system and contributes to the development of work skills. According to scientific publications, self-esteem develops through assessment of one's abilities and the response of others to those abilities. Adolescents engaged in sports always receive instructions and the assessment of their activities from their coaches. In addition, adolescents can soon notice the improvement of their physical abilities and compare them with those of their peers in the team. A game is first of all an activity. Considering team sport - in our 
case basketball, involvement in playing influences the physical, physiological and psychosocial components of a sporting individual, develops his/her behavior, character, creativity, shapes the value system, develops physical abilities and influences the development of work skills. Team sport is always associated with roles, with a clear dominant goal, that later on can also reflect on the individual - a team player (Svoboda, Vaněk, 1986).

The study is focused on young basketball players of both genders. Before the study, a comprehensive literature review including Czech and foreign scientific sources was made. The scientific problem is the lack of the research that would reveal up how team sports experience influence the development of an individual. Moreover, not many researchers have investigated gender differences in multi dimensional physical self-concept recently. Thus, this study was conducted to reveal gender and age differences of the two chosen domains of physical self-concept - global self-esteem and body fat. Some previous studies revealed that males scored higher than females in global self-esteem (Klomsten et al., 2004). S. Laskiene et al (2007) found that the score of self-esteem in male adolescents both engaged in sports and not engaged in sports was higher than that of their female counterparts. This is related with psychosocial peculiarities typical of adolescence period. But do only male basketball players score higher than females? Do they score higher on the other dimensions of physical self-concept such as body fat or global self-esteem as well?

Our survey study allows suggesting that there is no decent research focusing on team-sport in the Czech Republic, even if physical self-concept and its domains have been a widely discussed topic in the last decade. There are some similar studies made abroad (e. g. Klomsten et al., 2004), which not only deal with physical self-concept and its domains, but also analyzes it in athletes-adults and adolescents engaged in different kinds of sports.

The aim of the study was to identify age and gender differences in global self-esteem and body fat in adolescents - basketball players.

Objectives:

- To determine the differences of global selfesteem according to the age and gender of adolescents-basketball players

- To determine the differences of body fat according to the age and gender of adolescentsbasketball players
Referring to the analyzed research literature we framed the following hypotheses:

H 1: Males will produce significantly higher results in global self-esteem than females regardless of their age;

H 2: Body fat will score higher as negative evaluation in females than males regardless of their age.

The object of the research was global selfesteem and body fat in adolescents engaged in basketball.

\section{RESEARCH METHODS AND ORGANIZATION}

Research contingent characteristics. Our study sample consisted of 95 adolescents - basketball players (54 males and 41 females). The mean age of the players was 15.5 years. Since gender and age were the focus of this study, the adolescents were divided into two age groups. The first age group included adolescents aged $13-15$ years and it consisted of 23 males with the mean age of 14.3 years, and 17 females with the mean age of 14.2 years. The second age group (including 16-18 year-old players) consisted of 31 males with the mean age of 16.8 years and 24 females with the mean age of 16.6 years. The participants were students from the Sport Gymnasiums and clubs in Prague and Brno (Czech Republic). The players (including both genders), who had been training for more than four years $(86 \%)$, declared the following achievements: champions in the Czech Republic, the prizemen / women in the basketball championships in the Czech Republic, representative players of extra league, the winners of school basketball matches, etc.

The limitation of the study can be a small number of respondents. We applied to 7 gymnasiums and clubs, but only very few of them gave us permission to carry out questioning.

Introductory Questionnaire. An ordinary Introductory Questionnaire of 20 items was compiled in order to be able to describe the research participants (author - V. Medišauskaitè).

Physical Self Description Questionnaire PSDQ (Marsh et al., 1994). The Physical SelfDescription Questionnaire (PSDQ) is a 70-item questionnaire that measures nine specific components: Appearance, Strength, Endurance, Flexibility, Health Coordination, Physical Activity, Body Fat (e. g., "I have too much fat on my body," "My stomach is too big") and Sport Competence, one 
Global Physical Scale and one Global Self Esteem Scale (e. g., "Overall, most things I do turn out well," "Overall, I am no good"). All PSDQ scales contain six items except for the Health and Global Esteem subscale that has eight items. Each PSDQ item is an ordinary declarative statement, and the participants respond to it using a 6-point truefalse response scale. The PSDQ was designed for adolescents.

The Questionnaire was standardized in Australia, SELF-Concept Research Centre, and validated in a number of studies in Australia and other countries in the adolescent population (http://self. uws.edu.au/Conferences/2006/Abstracts.pdf). The inventory was adopted for the use in the Czech Republic. Unfortunately, we did not succeed in finding an adequate standardized instrument in the Czech Republic.

Statistical Methods. The statistical methods used were MANOVA and correlation. Significance level was chosen to be $10 \%$.

The Procedure. When we were granted permission from the sport school headmasters to perform the study, we carried out our questioning. Students, who agreed to participate, completed the questionnaires. They were informed that the questionnaire was not a test and that there were no right and wrong answers. The participants were told that they could stop participating in the study at any time. They were assured that their answers would be kept confidential. The participants were not allowed to talk to each other during the study, except to ask for help from the researcher if they did not understand the questions. To ensure uniformity in the administration of the questionnaire, the same set of directions were followed each time by the same researcher. The procedure including explaining instructions took $25-30$ minutes.

\section{RESEARCH RESULTS}

The results of our current study revealed statistically significant difference $(p<0.01)$ between global self-esteem and age. Global self-esteem was evaluated more positively in younger adolescents - basketball players - than in the older ones regardless of their gender (Table 1, Fig. 1).

The significant difference $(\mathrm{p}<0.01)$ was found between body fat and gender. The results indicate that females evaluated their body fat very negatively compared to males, regardless of their age. Females thought they were not skinny enough,
Table 1. MANOVA result - domain
GLOBAL SELF-ESTEEM and interac-
tion between the variables

Note. Statistically significant difference $(\mathrm{p}<0.01)$ was found in Global Self-esteem - Age. df - degree of freedom; SE* — Global Self-esteem; Sq. A.* - square amount; disp* — dispersion; $\mathrm{F}^{*}$ — the value of test criterion. $\mathrm{N}=95$.

Figure 1. The means of partial least squares (global self-esteem in relation with age)

Note. Wilksov lambda $=0.89622$ $\mathrm{F}(11.76)=0.80009, \mathrm{p}=0.63946$

Decomposition of effective hypothesis. Vertical column indicates 0.95 interval of reliability.

\begin{tabular}{|c|c|c|c|c|c|}
\hline Effect & df & $\begin{array}{c}\text { SE }^{*} \\
\text { Sq. A.* }\end{array}$ & $\begin{array}{c}\text { SE* } \\
\text { disp.* }\end{array}$ & $\begin{array}{c}\mathrm{SE}^{*} \\
\mathrm{~F}^{*}\end{array}$ & $\begin{array}{l}\text { SE* }^{*} \\
\mathbf{p}^{*}\end{array}$ \\
\hline Gender & 1 & 23.9227 & 23.92 & 2.22 & 0.13 \\
\hline Age group & 1 & 51.927 & 51.92 & 4.82 & 0.03 \\
\hline Gender*Age_group & 1 & 4.46720 & 4.467 & 0.41 & 0.52 \\
\hline Error & 86 & 924.93 & 10.75 & & \\
\hline Total & 93 & 1003.92 & & & \\
\hline
\end{tabular}

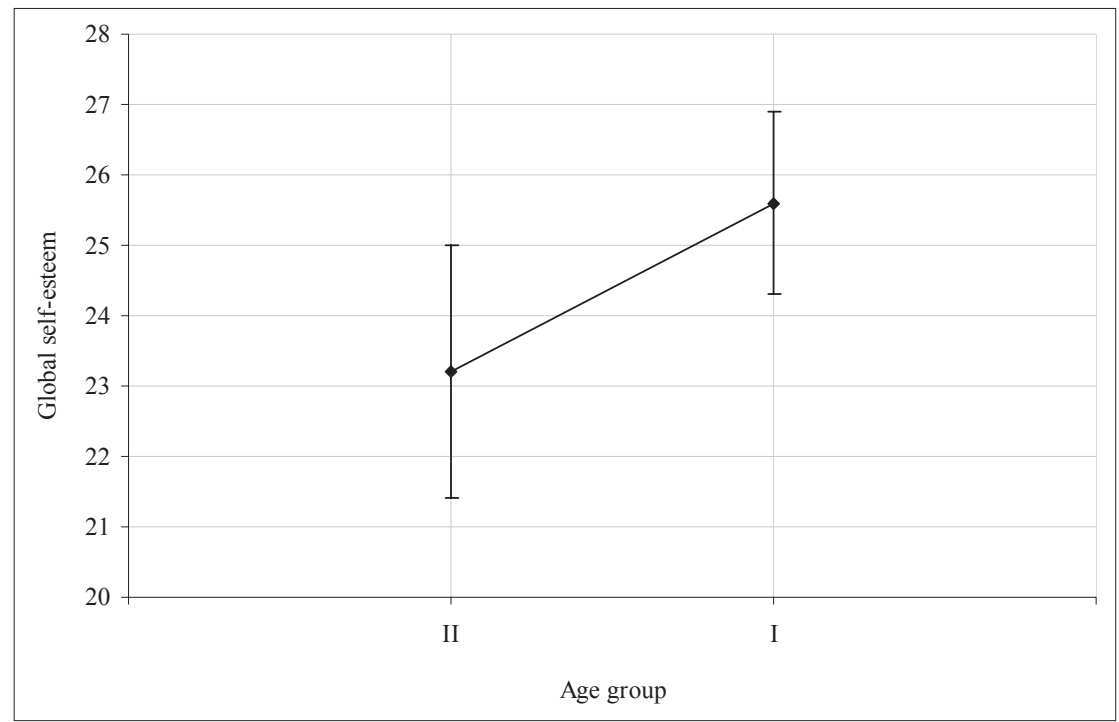




\begin{tabular}{|l|c|c|c|c|c|}
\hline \multicolumn{1}{|c|}{ Effect } & df & $\begin{array}{c}\text { BF* } \\
\text { Sq. A.* }\end{array}$ & $\begin{array}{c}\mathbf{B F}^{*} \\
\mathbf{d i s p}{ }^{*}\end{array}$ & $\begin{array}{c}\mathbf{B F}^{*} \\
\mathbf{F}^{*}\end{array}$ & $\begin{array}{c}\mathbf{B F}^{*} \\
\mathbf{p}^{*}\end{array}$ \\
\hline Gender & 1 & 355.197 & 355.19 & 8.87 & 0.00 \\
\hline Age group & 1 & 15.51 & 15.51 & 0.38 & 0.54 \\
\hline Gender*Age_group & 1 & 6.33747 & 6.3374 & 0.15 & 0.69 \\
\hline Error & 86 & 3440.9 & 40.011 & & \\
\hline Total & 93 & 3914.9 & & & \\
\hline
\end{tabular}

Table 2. MANOVA result - domain BODY FAT and interaction between the variables

Note. Statistically significant difference $(p<0.01)$ was found in Body Fat - Gender. df - degree of freedom; $\mathrm{BF}^{*}$ - body fat; Sq. A.* - square amount; disp* - dispersion; $\mathrm{F}^{*}$ - the value of test criterion. $\mathrm{N}=95$.

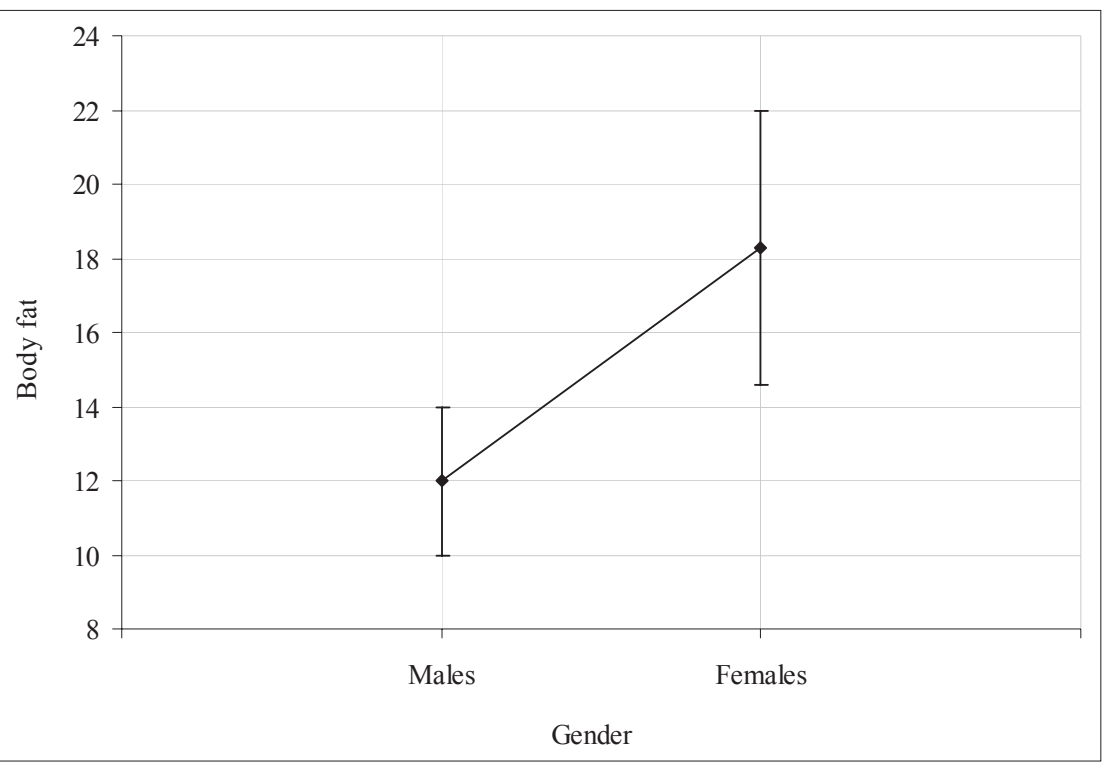

Figure 2. The means of partial least squares (body fat in relation with gender)

Note. Wilksov lambda $=0.74982$, $\mathrm{F}(11.76)=2.3052, \mathrm{p}=0.01695$

Decomposition of effective hypothesis. Vertical column indicates 0.95 interval of reliability.

some of them supposed they were fat, or everybody thought they were fat and unattractive (Table 2, Fig. 2).

\section{DISCUSSION}

The western society demands slenderness from men and women. It is expected from a woman to be slim and well-proportioned, and a man to be slim and muscular. Previous studies have shown that females, in particular, are critical about their appearance and body weight (Hoyt, Kogan, 2001; Rosenblum, Lewis, 1999). The study of T. A. Klomsten et al. (2004) support this conclusion - that is, the female adolescents demonstrated a low score in body fat even if they were engaged in sports as out of school activities. The author did not indicate any significant differences in age.

The respondents of our study have their goal of life - sport, moreover, a team sport, which takes time, perfectly shapes their bodies. As our results showed, there were some points proving it was not exactly what we thought. Female adolescents basketball players reported higher levels of body dissatisfaction than male adolescents $(p<0.01)$, and that also confirms some previous findings in sportive or non-sportive adolescents (but not basketball players) by such researchers as A. J. O'Dea, S. Abraham (1999), M. Blatný (2001), L. Fialová (2001), M. P. McCabe, L. Ricciardelli (2004) and others. The topic of adolescents engaged and not engaged in sports is widely discussed by L. Fialová $(2001,2007)$, too. Moreover, the author found that the youngest girls were more satisfied with their physical appearance than boys, but in all other age groups the boys were more satisfied than girls. Considering the body shape and body fat in non-sportive Czech adolescent population, the evaluation of males is always higher than of females (Fialová, 2001, 2007). We suppose that the negative body fat evaluation mainly comes from the environmental pressure. Media, journals, fashion are slenderness oriented 'pictures', which promise success and power. The investigated females - young basketball players - were fit from the perspective of the researcher, but demanding and critical about their bodies from the perspective of themselves.

The previous study of T. A. Klomsten et al. (2004) revealed that both age and gender were significantly related to global self-esteem in adolescents. Males scored significantly higher than 
females (students were engaged in out of school activities - different kind of sports, Norwegian population). In our study the results revealed statistically significant difference $(p<0.01)$ between global self-esteem and age, but not gender. Selfesteem was found to be more positive in younger adolescents - basketball players - than in older players, and this conclusion does not support the previous study results of M. Blatný (2001) or K. C. Kling et al. (1999) considering gender, where studies provide evidence that males score higher on measures of global self-esteem than females, but the difference is small (non-athlete gymnasium students), or of F. Alasker and D. Olweus (1992) where self-esteem also varies according to gender in adolescents (non-athletes), and the previous study of S. Laskiene et al. (2007) where male adolescents both engaged in sports and not engaged in sports scored higher in self-esteem than their female counterparts did. It is worth noting that S. Harter and A. Monsour (1992) reported that global self-esteem is stable during adolescence and increases slightly over the period. We suppose the outcome in our investigated group of athletes (with self-esteem decreasing with age) could be related to adolescence itself, the period of transition, and that complicates our discussion and prevents us from some concrete considerations. As we know, the transition period involves not only biological, cognitive, but psychosocial development, too
(Macek, 2003). Our obtained results could also explain that probably younger adolescents are not so focused on being very good players as the older ones. With age the requirements to achieve higher results are increasing, so self-esteem could have a tendency to decrease as not being or feeling "perfect" or not meeting the requirements regardless of gender. Basketball is more likely to be seen as a masculine sport what in theory could "equalize" the sport values and competences of both genders. However, it is hard to make a grounded conclusion or to offer an explanation without any further investigations.

\section{CONCLUSIONS}

1. The results revealed statistically significant difference $(p<0.01)$ between global self-esteem and age, regardless of gender. Global self-esteem was found to be more positive in younger adolescents - basketball players - than in older players.

2. A significant difference $(\mathrm{p}<0.01)$ was found between body fat and gender. The results indicated that females evaluated their body much more negatively compared to males, regardless of their age. Females may have thought that they were not skinny enough, some of them thought they were fat or unattractive.

\section{REFERENCES}

Alasker, F., Olweus, D. (1992). Stability of global selfevaluations in early adolescence: A cohort longitudinal study [Abstract]. Journal of Research on Adolescence, 1, $123-145$.

Blatný, M. (2001). Sebepojetí v osobnostním kontextu. Brno: MU.

Fialová, L. (2001). Body image jako součást sebepojetí člověka. Praha: Karolinum.

Fialová, L. (2007). Metody zkoumání nespokojenosti s tělem. Česká kinantropologie, 11 (3), 41-47.

Fox, K. R. (2000). Self-esteem, self-perceptions and exercise. International Journal of Sport Psychology, 31, 228-240.

Harter, S., Monsour, A. (1992). Development analysis of conflict caused by opposing attributes in the adolescent self-portrait. Developmental Psychology, 28 (2), 20.

Harter, S. (1999). The Construction of the Self: A developmental perspective. New York: The Guilford Press.

Hoyt, W. D., Kogan, L. R. (2001). Satisfaction with body image and peer relationships for males and females in a college environment. Sex Roles, 45, 199-215.

Kling, K. C., Hyde, J., Showers, C., Buswell, B. (1999). Gender differences in self-esteem: A meta-analysis. Psychological Bulletin, 125 (4), 470—500.
Klomsten, A. T., Skaalvik, E. M., Espnes, G. A. (2003). Physical self-concept and sports: Do gender differences still exist? Sex Roles, 50 (2003), 119-127.

Laskienė, S., Puniškienè, R., Laskytè, A. (2007). Peculiarities of preference values, personal qualities and selfesteem of the teenagers involved in sports: International scientific conference "Sport a kvalita života". Proceedings book. Brno: Masaryk University. P. 1-15.

Macek, P. (2003). Adolescence. Praha: Portál.

Macek, P., Lacinová, L. (2006). Vztahy v dospívání. Barrister \& Principal.

Marsh, H. W., Richards, G. E., Johnson, S., Roche, L., Tremayne, P. (1994). Physical Self-Description Questionnaire: Psychometric properties and a multitrait-multimethod analysis of relations to existing instruments. Sport and Exercise Psychology, 16, 207-305.

Mccabe, M. P., Ricciardelli, L. (2004). A longitudinal study of pubertal timing and extreme body change behaviors among adolescent boys and girls. Adolescence, $39,145-166$.

Moreno, J. A., Cervello, E. (2005). Physical self-perception in Spanish adolescents: Effects of gender and involvement in physical activity. Journal of Human Movement Studies, 48, 291-311. 
O’Dea, A. J., Abraham, S. (1999). Association between self-concept and body weight, gender, and pubertal development among male and female adolescents. Adolescence, 34, 69-79.

Oweis, P., Spinks, W. L. (2001). Psychological outcomes of physical activity: A theoretical perspective. Journal of
Human Movement Studies, 40, 351-375.

Rosenblum, G. D., Lewis, M. (1999). The relations among body image, physical attractiveness, and body mass in adolescence. Child Development, 70, 50-64.

Svoboda, B., Vaněk, M. (1986). Psychologie sportovnich her. Praha: Olympie.

\title{
KREPŠINI ŽAIDŽIANČIŲ PAAUGLIŲ BENDROSIOS SAVIGARBOS IR SAVO KŪNO RIEBALŲ SUVOKIMAS
}

\author{
Vilma Medišauskaite் ${ }^{1}$, Skaistė Laskien $\dot{e}^{2}$, Martin Sebera $^{1}$ \\ Masaryk universitetas, Brno, Čekija ${ }^{l}$, Lietuvos kūno kultūros akademija ${ }^{2}$ Kaunas, Lietuva
}

\section{SANTRAUKA}

Anot S. Harter (1999), protinè ir moralinè branda, tobulèjimas, taip pat kaip išvaizda, fiziniai gebėjimai šiomis dienomis yra vis dažniau suvokiami kaip atsparos taškai vertinant mūsų identitetą ir yra ypač svarbūs paauglysteje. Fizinio $A \check{s}$ komponentu (išvaizdos, savigarbos, fizinès kompetencijos ir kt.) vystymasis paskutini dešimtmetị traukia vis didesni mokslininkų dèmesi (Fox, 2000).

Tyrimo tikslas - nustatyti paauglių krepšininkų bendrojo $A \check{s}$ vaizdo ir fizinio $A \check{s}$ vaizdo suvokimą, atsižvelgiant $\mathfrak{i}$ amžių ir lytị. Bendrasis $A \check{s}$ vaizdas yra suvokiamas kaip bendras pozityvus ar negatyvus savojo $A \check{s}$ vertinimas, neatsižvelgiant ị konkrečią sritị ar situaciją (Macek, Lacinová, 2006). Fizinio Aš vaizdo suvokimas buvo tiriamas per požiūri i savo kūno masę - konkrečiau, i kūno riebalus (pvz., aš manau, kad turiu antsvorị, esu apkūnus pilvo srityje ir pan.) (Marsh et al., 1994).

Tiriamaji kontingentą sudare 95 paaugliai krepšininkai, iš jų 41 mergina ir 54 vaikinai. Tiriamieji treniruojasi Brno ir Prahos (Čekijos) sporto gimnazijose ir klubuose. Buvo sudarytos dvi tiriamuju amžiaus grupès (I - 13-15 m. paaugliai; II - 16-18 m. paaugliai). Tiriamujų charakteristikai apibrěžti naudojome ¿̇vadini 20 klausimu klausimyną, kuri sudare pagrindinis straipsnio autorius. Bendrasis $A \check{s}$ vaizdas ir kūno riebalų vertinimas buvo tirti naudojant fizinio $A \check{s}$ vertinimo klausimyną (Marsh et al., 1994). Abu tyrimo metu naudoti klausimynai yra anoniminiai. Norint užtikrinti apklausos kokybę, kiekvieną kartą apklausą atliko tas pats tyrèjas. Rezultatų statistiniam apdorojimui taikyta MANOVA ir koreliacija. Reikšmingumo lygmuo $-10 \%$.

Tyrimo rezultatai parodè neigiamą merginų savo fizinio kūno suvokimą: pastebimas statistiškai patikimas skirtumas ( $\mathrm{p}<0,01)$ lyties požiūriu, nepaisant amžiaus. Kitas mūsų žingsnis buvo išsiaiškinti, kaip paaugliai krepšininkai vertina savo bendraji $A \breve{s}$ vaizdą. Pagal gautus rezultatus bendrasis $A \breve{s}$ vaizdas yra reikšmingai pozityviau vertinamas jaunesnių krepšininkų grupeje, nepaisant lyčių skirtumo $(p<0,01)$.

Raktažodžiai: bendrasis $A \check{s}$ vaizdas, kūno riebalai, paauglystè, amžius, lytis, krepšinis.

Gauta 2008 m. spalio $2 \mathrm{~d}$.

Received on October 2, 2008

Priimta 2008 m. gruodžio $9 \mathrm{~d}$.

Accepted on December 9, 2008

\author{
Vilma Medišauskaitė \\ Masaryk University \\ (Masaryk universitetas) \\ Sladkeho 13, 13617 Brno \\ Czech Republic (Čekijos Respublika) \\ $\mathrm{Tel}+420608430425$ \\ E-mailmed.vilma@gmail.com
}

